\title{
Effect of nitrogen rates and application times on growth and yield of maize (Zea mays L.)
}

Shazma Anwar, Waseem Ullah, Muhammad Islam*, Muhammad Shafi, Asif Iqbal and Madeeha Alamzeb

Department of Agronomy, Faculty of Crop Production Sciences, The University of Agriculture, Peshawar-Pakistan *Corresponding author's email: islamswati439@yahoo.com

Citation

Shazma Anwar, Waseem Ullah, Muhammad Islam, Muhammad Shafi, Asif Iqbal and Madeeha Alamzeb. Effect of nitrogen rates and application times on growth and yield of maize (Zea mays L.). Pure and Applied Biology. Vol. 6, Issue 3, pp908-916. http://dx.doi.org/10.19045/bspab.2017.60096

\begin{tabular}{llll}
\hline \hline Received: 14/03/2017 & Revised: 13/07/2017 & Accepted: 17/07/2017 & Online First: 21/072017 \\
\hline
\end{tabular}

\section{Abstract}

A field experiment was designed to study the effect of nitrogen rates and application time on growth and yield of maize at Agronomy Research Farm, The University of Agriculture, Peshawar during summer 2014. An experiment was laid out in randomized complete block design using three replications. Four nitrogen rates $\left(80,120,160\right.$ and $\left.200 \mathrm{~kg} \mathrm{ha}^{-1}\right)$ were applied as full at sowing ( AT1), $1 / 2$ at sowing $+1 / 2$ at 25 days after sowing (AT2) and $1 / 3$ at sowing + $1 / 3$ at 25 days after sowing $+1 / 3$ at 50 days after sowing (AT3). Results showed that all studied parameters were significantly affected by $\mathrm{N}$-levels. Maximum mean leaf area $\left(258.19 \mathrm{~cm}^{2}\right)$, plant height (188 cm), grains ear $^{-1}$ (369), 1000-grains weight (245 g), biological yield (9593 kg ha-1), grain yield (4109 $\mathrm{kg} \mathrm{ha}^{-1}$ ) and harvest index (42\%) were observed with application of $160 \mathrm{~kg} \mathrm{~N}$ $\mathrm{ha}^{-1}$. The results further revealed that maximum mean leaf area $\left(260 \mathrm{~cm}^{2}\right)$, plant height $(184 \mathrm{~cm})$, grains ear $^{-1}(380)$, biological yield (9195 $\left.\mathrm{kg} \mathrm{ha}^{-1}\right)$, 1000-grains weight (247 g) and grain yield $\left(3707 \mathrm{~kg} \mathrm{ha}^{-1}\right)$ were recorded when $\mathrm{N}$ was applied $1 / 2$ at sowing $+1 / 2$ at 25 days after sowing. The interactive effect of $\mathrm{N}$ rates and application time was found significant for mean leaf area. It was concluded that nitrogen at the rate of $160 \mathrm{~kg} \mathrm{ha}^{-1}$ and application of $\mathrm{N} 1 / 2$ at sowing $+1 / 2$ at 25 days after sowing is most reliable for yield and production of maize crop in the study region and thus optional for general use in agriculture.

Keywords: Maize (Zea mays); Nitrogen rates; Application timing; Yield and yield components

\section{Introduction}

Maize (Zea mays) after wheat and rice is the $3^{\text {rd }}$ main cereal grain crop. It is used as a staple food by human being, also used as feed for livestock and raw material for industry [1]. In Pakistan it was planted on 0.911 million hectares area, with total production of 3.11 million tons during 20112012. In Khyber Pakhtunkhwa maize was grown on 0.441 million hectares, with production of 0.801 million tons and the average yield recorded was only $1.81 \mathrm{t} \mathrm{ha}^{-1}$ [2].

Nitrogen is vital in crop productivity which plays role in accelerating yield and gave optimum economic return [3] and its deficiency will constitutes in low yield and productivity in cereal crops [4]. Efficient 
nitrogen use by maize permits use of appropriate source in an adequate amount, at proper timing and suitable application rates $[5,6]$. By applying proper dose and at suitable timing nitrogen use efficiency can be improved [7]. While recommending a single level of $\mathrm{N}$ for corn is very difficult rather incredible without seeing the distinction in location and many other factors. Thus, various scientists found optimum maize yield using 140 to $250 \mathrm{~kg} \mathrm{~N}$ $\mathrm{ha}^{-1}$ [8]. [9] stated, that a split application of $185 \mathrm{~kg} \mathrm{~N} \mathrm{ha}^{-1}$ was suitable to attain optimum maize yield. Timing of $\mathrm{N}$ application is also deliberated as the best managing strategy and is very crucial for maize production [10]. Nitrogen use efficiency could be enhanced by applying it at proper timing because it diminishes the menace of losses through denitrification, immobilization and leaching [6]. Rapid growth and nutrient uptake period of cereal crops was also testified to be about 35 days after emergence at the eight-leaf development stage.

The present experiment was aimed to study the effect of nitrogen rates and application timings in order to investigate appropriate nitrogen fertilization for optimum maize yield and yield components as it is of vital importance and is a major yield influential factor as compared to other nutrients required by the plants.

\section{Materials and methods}

A field experiment was conducted to investigate effects of nitrogen levels (80, 120, 160 and $200 \mathrm{~kg} \mathrm{ha}^{-1}$ ) and application timings (full at sowing, $1 / 2$ at sowing and $1 / 2$ at 25 days after sowing, $1 / 3$ at sowing $+1 / 3$ at 25 days after sowing $+1 / 3$ at 50 days after sowing) on growth and yield of maize at Agronomy Research Farm, The University of Agriculture, Peshawar, during summer 2014. The research farm is situated at $34.01^{\circ} \mathrm{N}$ latitude, $71.35^{\circ} \mathrm{E}$ longitude with an altitude of $350 \mathrm{~m}$ from above sea level in Peshawar valley. The experiment was carried out in randomized complete block design (RCBD) having three replications with a plot size of $3 \mathrm{~m} \times 3.5 \mathrm{~m}$. Plant to plant distance was $20 \mathrm{~cm}$ and row to row distance was $75 \mathrm{~cm}$. Each plot comprised of $3 \mathrm{~m}$ long five rows. Data were recorded on mean leaf area, plant height, days to physiological maturity, number of grains ear ${ }^{-1}$, 1000-grains weight, biological yield, grain yield and harvest index. Leaf area was calculated by measuring the lengths and widths of all leaves of five representative plants from each treatment at silking.

The mean single leaf area was calculated by the formula

(Leaf area $=$ Leaf length $\times$ Leaf width $\times$ $0.75)$.

Data on plant height $(\mathrm{cm})$ at physiological maturity was recorded from base to the tip of tassel with the help of meter rod by selecting ten plants randomly from each plot and then averaged were worked out. Days to physiological maturity were recorded from the date of sowing till date when all the plants gets physiological maturity in each treatment. Number of grains ear ${ }^{-1}$ was calculated on ten randomly selected ears from each plot and were threshed and was averaged. After threshing, Grain weight of randomly 1000 grains was taken from seed lot of each plot and was weighted with the help of electronic balance so thousand grain weight were recorded. Data on biological yield was recorded by harvesting three central rows in each plot, the plants along with cobs were sun dried for several days and weighed, and then converted into biological yield $\mathrm{kg} \mathrm{ha}^{-1}$ by using formula. Biological yield $\left(\mathrm{kgha}^{-1}\right)=$ Biological yield per three rows $\times 10000$ No. of rows $\times$ row length $\times$ R-R distance

Three central rows of each treatment was harvested, dried, threshed and weighted and then was converted into grain yield $\left(\mathrm{kg} \mathrm{ha}^{-1}\right)$. Grain yield $=$ Grain yield per three rows $\times 10000$ No. of rows $\times$ row length $\times$ R-R distance 
Harvest index for each treatment is calculated by using the following formula.

Harvest index $=$ Economic yield $\times 100$

\section{Statistical analysis}

$$
\text { Biological yield }
$$

Data was statistically analyzed according to [11] and means was compared through LSD test $(\mathrm{P} \leq 0.05)$.

\section{Results}

Mean leaf area $\left(\mathrm{cm}^{2}\right)$

Mean leaf area of maize considerably increased by increasing nitrogen rates (Table 1) and maximum mean leaf area (258.19 $\mathrm{cm}^{2}$ ) was measured in plots treated with 160 $\mathrm{kg} \mathrm{N} \mathrm{ha}{ }^{-1}$, whereas minimum mean leaf area $\left(245.35 \mathrm{~cm}^{2}\right)$ was recorded plots supplied with $80 \mathrm{~kg} \mathrm{~N} \mathrm{ha}^{-1}$. Similarly application of whole dose of $\mathrm{N}$ at the time of sowing resulted minimum mean leaf area (248.91 $\mathrm{cm}^{2}$ ) was observed in plots received full $\mathrm{N}$ at sowing time, while maximum mean leaf area of $\left(260.93 \mathrm{~cm}^{2}\right)$ be recorded in plots receiving $\mathrm{N}$ half at time of sowing and at 25 days interval after sowing. Control plot resulted lowest mean leaf area $\left(215.03 \mathrm{~cm}^{2}\right)$ as compared to rest $\left(256.04 \mathrm{~cm}^{2}\right)$. Interaction of nitrogen rates into application timing had significant effect on mean leaf area of maize. The mean leaf area increases with increase in nitrogen rates with application timing as shown in Figure 1.

Table 1. Mean leaf area, plant height, days to maturity, and number of grains ear ${ }^{-1}$ of maize as affected by nitrogen rates and its application times

\begin{tabular}{|l|l|l|l|l|}
\hline $\begin{array}{l}\text { Nitrogen } \\
\text { rates }\left(\mathbf{k g ~ h a}^{-1}\right)\end{array}$ & $\begin{array}{l}\text { Mean leaf } \\
\text { area }(\mathbf{c m} 2)\end{array}$ & $\begin{array}{l}\text { Plant } \\
\text { height }(\mathbf{c m})\end{array}$ & $\begin{array}{l}\text { Days } \\
\text { to maturity }\end{array}$ & $\begin{array}{l}\text { Number of } \\
\text { grains ear }\end{array}$ \\
\hline 80 & $245.35 \mathrm{~b}$ & $167.89 \mathrm{c}$ & $98.56 \mathrm{~b}$ & $335.22 \mathrm{~b}$ \\
\hline 120 & $256.43 \mathrm{a}$ & $174.22 \mathrm{~b}$ & $100.89 \mathrm{a}$ & $341.33 \mathrm{ab}$ \\
\hline 160 & $258.19 \mathrm{a}$ & $188.00 \mathrm{a}$ & $101.44 \mathrm{a}$ & $369.67 \mathrm{a}$ \\
\hline 200 & $264.21 \mathrm{a}$ & $190.33 \mathrm{a}$ & $101.56 \mathrm{a}$ & $374.22 \mathrm{a}$ \\
\hline LSD & 10.6 & 5.61 & 1.09 & 32.29 \\
\hline Application times (AT) & & & & \\
\hline AT1 & $248.91 \mathrm{~b}$ & $176.58 \mathrm{a}$ & $100.08 \mathrm{~b}$ & $340.25 \mathrm{~b}$ \\
\hline AT2 & $260.93 \mathrm{a}$ & $184.25 \mathrm{a}$ & $101.42 \mathrm{a}$ & $380.75 \mathrm{a}$ \\
\hline AT3 & $258.30 \mathrm{a}$ & $179.50 \mathrm{ab}$ & $100.33 \mathrm{~b}$ & $344.33 \mathrm{a}$ \\
\hline LSD & 9.18 & 4.86 & 0.94 & 27.97 \\
\hline Control & $215.03 \mathrm{~b}$ & $164.66 \mathrm{~b}$ & $96.66 \mathrm{~b}$ & $257.33 \mathrm{~b}$ \\
\hline Rest & $256.04 \mathrm{a}$ & $180.11 \mathrm{a}$ & $100.61 \mathrm{a}$ & $355.11 \mathrm{a}$ \\
\hline N x AT & 18.36 & Ns & Ns & Ns \\
\hline
\end{tabular}

Note: $($ AT $1=$ full at sowing, AT2 $=1 / 2$ at sowing $+1 / 2$ at 25 days after sowing, AT3 $=1 / 3$ at sowing $+1 / 3$ at 25 days after sowing $+1 / 3$ at 50 days after sowing).

Means of same category followed by different letter are significantly different from one another at $\mathrm{p} \leq 0.05 \%$. 


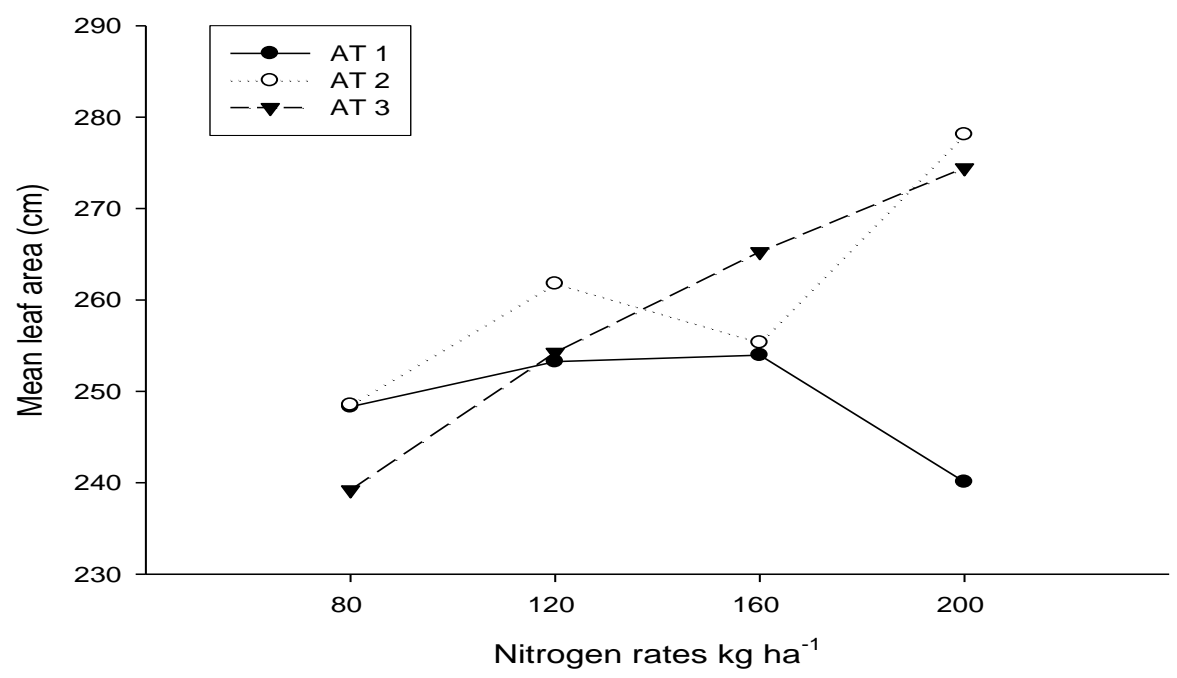

Figure 1. Interaction of nitrogen rates and application timing on mean leaf area of maize

Plant height (cm)

Data regarding plant height varied significantly nitrogen levels, application timing and control vs. rest, while $\mathrm{N} \times \mathrm{AT}$ non-significant (Table 1). Mean data indicated that taller plants $(188 \mathrm{~cm})$ were observed in plots received $160 \mathrm{~kg} \mathrm{~N} \mathrm{ha}^{-1}$. Whereas dwarf plants $(167.89 \mathrm{~cm})$ was observed in plots treated with $80 \mathrm{~kg} \mathrm{~N} \mathrm{ha}^{-1}$. Regarding application timings minimum plant height $(176.58 \mathrm{~cm})$ was noticed in plots received $\mathrm{N}$ full at sowing as application timing $\left(\mathrm{AT}_{1}\right)$ while maximum plant height $(184.25 \mathrm{~cm})$ was recorded in plots received $\mathrm{N}$ in two splits that is half at sowing time and other half at 25 days interval after sowing. Data further revealed that control plots attained minimum plant height as compared to treated.

Days to physiological maturity

Days to physiological maturity significantly affected by nitrogen, its application timings and control vs. rest, while interaction between the two factors was not significant (Table 1). Maximum days to maturity (101) were taken by plots received nitrogen at the rate of $160 \mathrm{~kg} \mathrm{ha}^{-1}$. While minimum days to maturity (98) were observed in the plots fertilized $80 \quad \mathrm{~kg} \quad \mathrm{~N} \quad \mathrm{ha}^{-1}$. Regarding application times delayed maturity (101days) was noticed in the plots supplied nitrogen half at sowing and half at interval of 25 days after sowing, while early maturity (100 days) was observed in plots fertilized with full dose of $\mathrm{N}$ at sowing time. All treated plots took more days to maturity than control plots.

Number of grains ear-1

Table 1 represents a significant effect of nitrogen rates, application timing and control vs. rest on number of grains ear ${ }^{-1}$ of maize, while $\mathrm{N} \times \mathrm{AT}$ was found nonsignificant. Increasing $\mathrm{N}$ rates significantly increased grains ear ${ }^{-1}$ from $335\left(80 \mathrm{~kg} \mathrm{~N}^{-}\right.$ $\left.{ }^{1}\right)$ to $369\left(160 \mathrm{~kg} \mathrm{~N} \mathrm{ha}^{-1}\right)$. In case of AT more grains ear ${ }^{-1}$ (380) were counted in plots supplied with $\mathrm{N}$ half at sowing plus half at 25 days after sowing, while less grains ear ${ }^{-1}$ (340) were recorded in plots to which nitrogen was applied full at sowing time. In planned mean comparison, control plots produced lower grains ear ${ }^{-1}$ (257) as compared to fertilized plots which produced 355 grains ear ${ }^{-1}$.

\section{Thousand grains weight (g)}

Thousand grains weight of maize considerably differed by nitrogen rates, its application timings and control vs. rest, 
while interaction between $\mathrm{N}$ and AT was found non-significant (Table 2). Maximum 1000-grains weight (245 g) was noticed in plots fertilized with (160 kg N ha $\left.{ }^{-1}\right)$. While minimum 1000-grains weight (225 g) was recorded in plots received $80 \mathrm{~kg} \mathrm{~N} \mathrm{ha}^{-1}$. In application timings higher 1000-grains weight $(247 \mathrm{~g})$ was recorded in plots to which nitrogen was applied $1 / 2$ as AT1 and $1 / 2$ as AT2, while lower thousand grain weight $(234 \mathrm{~g})$ was noted in plots to which whole $\mathrm{N}$ was applied at sowing time. Furthermore, it is evident from the planned mean data that rest experimental units produced higher thousand grains weight (238g) when compared to control (215g).

Table 2. Thousand grains weight, biological yield, grain yield and harvest index of maize as affected by nitrogen rates and its application times

\begin{tabular}{|l|l|l|l|l|}
\hline $\begin{array}{l}\text { Nitrogen } \\
\text { rates }\left(\mathbf{k g ~ h a}^{-1}\right)\end{array}$ & $\begin{array}{l}\text { Thousand } \\
\text { grains weight }(\mathbf{g})\end{array}$ & $\begin{array}{l}\text { Biological } \\
\text { yield (kg ha-1) }\end{array}$ & $\left.\begin{array}{l}\text { Grain } \\
\text { yield (kg ha }\end{array} \mathbf{- 1}^{-1}\right)$ & $\begin{array}{l}\text { Harvest } \\
\text { Index (\%) }\end{array}$ \\
\hline 80 & $225.56 \mathrm{~b}$ & $7939.78 \mathrm{c}$ & $2877.44 \mathrm{c}$ & $36.23 \mathrm{bc}$ \\
\hline 120 & $236.67 \mathrm{a}$ & $8551.78 \mathrm{~b}$ & $3291.22 \mathrm{~b}$ & $38.67 \mathrm{~b}$ \\
\hline 160 & $245.56 \mathrm{a}$ & $9593.22 \mathrm{a}$ & $4109.89 \mathrm{a}$ & $42.94 \mathrm{a}$ \\
\hline 200 & $246.11 \mathrm{a}$ & $9593.44 \mathrm{a}$ & $4175.00 \mathrm{a}$ & $43.42 \mathrm{a}$ \\
\hline LSD & 10.87 & 598.93 & 191.06 & 3.39 \\
\hline Application Times (AT) & & & & \\
\hline AT1 & $234.17 \mathrm{~b}$ & $8443.17 \mathrm{~b}$ & $3466.17 \mathrm{~b}$ & $40.86 \mathrm{a}$ \\
\hline AT2 & $247.92 \mathrm{a}$ & $9195.58 \mathrm{a}$ & $3707.58 \mathrm{a}$ & $40.18 \mathrm{a}$ \\
\hline AT3 & $233.33 \mathrm{~b}$ & $9119.92 \mathrm{a}$ & $3666.42 \mathrm{a}$ & $40.20 \mathrm{a}$ \\
\hline LSD & 9.41 & 518.69 & 165.46 & $\mathrm{Ns}$ \\
\hline Control & $215.00 \mathrm{~b}$ & $7302.333 \mathrm{~b}$ & $2432.66 \mathrm{~b}$ & $33.59 \mathrm{~b}$ \\
\hline Rest & $238.47 \mathrm{a}$ & $8919.556 \mathrm{a}$ & $3613.38 \mathrm{a}$ & $40.41 \mathrm{a}$ \\
\hline N x AT & $\mathrm{ns}$ & $\mathrm{Ns}$ & $\mathrm{ns}$ & $\mathrm{Ns}$ \\
\hline
\end{tabular}

Note: $(\mathrm{AT} 1=$ full at sowing, AT2 $=1 / 2$ at sowing $+1 / 2$ at 25 days after sowing, AT3 $=1 / 3$ at sowing $+1 / 3$ at 25 days after sowing $+1 / 3$ at 50 days after sowing).

Means of same category followed by different letter are significantly different from one another at $\mathrm{p} \leq 0.05 \%$.

\section{Biological yield ( $\left.\mathrm{kg} \mathrm{ha}^{-1}\right)$}

A significant effect of nitrogen levels, application timings and control vs rest on biological yield of maize is presented in Table 2. Nitrogen applied at the rate of 160 $\mathrm{kg} \mathrm{ha}^{-1}$ resulted maximum biological yield (9593 kg ha-1) whereas $80 \mathrm{~kg} \mathrm{~N}$ ha-1 resulted minimum biological yield $(7939 \mathrm{~kg}$ $\mathrm{ha}^{-1}$ ) of maize. Regarding AT lower biological yield (8443 $\mathrm{kg} \mathrm{ha}^{-1}$ ) was recorded in plots fertilized with whole nitrogen at sowing time, while maximum biological yield (9195 kg ha-1) was noticed in plots treated with nitrogen $50 \%$ at sowing $+50 \%$ at 25 days after sowing. Similarly treated plots produced more biological yield than control plots.

Grain yield (kg ha-1)

Statistical analysis of data showed a significant difference of $\mathrm{N}$ levels, application timings and control vs. rest on grain yield of maize but interactive affect for $\mathrm{N}$ rates and application times was found to be non-significant (Table 2). Nitrogen applied at the rate of $160 \mathrm{~kg} \mathrm{ha}^{-1}$ produced maximum grain yield (4109.89 $\mathrm{kg} \mathrm{ha}^{-1}$ ). Whereas minimum grain yield $\left(2877 \mathrm{~kg} \mathrm{ha}^{-}\right.$ ${ }^{1}$ ) was produced by $\mathrm{N}$ applied at the rate of $80 \mathrm{~kg} \mathrm{ha}^{-1}$. In application timings higher grain yield (3707 $\mathrm{kg} \mathrm{ha}^{-1}$ ) was recorded in 
plots received nitrogen half at sowing + half at 25 days after sowing, while lower grain yield (3466 kg ha-1) was recorded when nitrogen was fertilized full at sowing. Similarly all treated plots resulted maximum grain yield (3613 $\mathrm{kg} \mathrm{ha}^{-1}$ ) as compared to control plots which produced minimum grain yield $\left(2432 \mathrm{~kg} \mathrm{ha}^{-1}\right)$.

\section{Harvest index (\%)}

Table 2 revealed that harvest index of maize was significantly affected by $\mathrm{N}$ rates while the effect of application timings, control vs. rest and $\mathrm{N} x$ AT was found non-significant. Maximum harvest index (42.94\%) was noticed in plots received $160 \mathrm{~kg} \mathrm{~N} \mathrm{ha}^{-1}$ ). While minimum harvest index (36\%) was recorded in plots treated with $80 \mathrm{~kg} \mathrm{~N} \mathrm{ha}^{-1}$.

\section{Discussion}

Application of nitrogen rates and application timing improved growth parameters (plant height and mean leaf area. Nitrogen applied at the rate of $160 \mathrm{~kg} \mathrm{ha}^{-1}$ produced maximum mean leaf area of maize. Increase in mean leaf area may be due to more vegetative growth due to higher level of $\mathrm{N}$, as $\mathrm{N}$ is key element which boosts up the growth. The higher rate of $\mathrm{N}$ application increased leaf area, so the given results are in correspondence with [12]. Leaf area also varied by nitrogen application timing and maximum mean leaf area was recorded in plots received $\mathrm{N}$ half at time of sowing and at 25 days interval after sowing. These results are in line with [12], stated that $\mathrm{N}$ in four to five splits can increase leaf area of maize. Higher plant height was recorded when nitrogen was applied at the rate of 160 $\mathrm{kg} \mathrm{ha}^{-1}$. It was might be due to increase in accumulation of dry matter as a result of more vigorous vegetative growth with the application of $\mathrm{N}$ fertilizer. These results are in line with [13] that $\mathrm{N}$ enhances the vegetative growth in maize. Increase in the rate of $\mathrm{N}$ leads to increase in plant height, and was also recorded by Imran et al. [14] and Wajid et al. [15] who investigated that higher nitrogen level influence plant height. Nitrogen application timing also showed a significant effect on plant height of maize. These results are in line with [12], stated that $\mathrm{N}$ in four to five splits can increase plant height of maize. Similarly [16] revealed that nitrogen in three splits can give maximum plant height in maize.

Days to physiological maturity was delayed by nitrogen levels and its time of application. Maximum days to maturity were noticed in the plots received $160 \mathrm{~kg} \mathrm{~N}$ $\mathrm{ha}^{-1}$. Higher doses of nitrogen delay maturity due to increase in vegetative growth. Similar finding were observed by Imran et al. [14] also stated that days to maturity delayed by increasing the rate of $\mathrm{N}$ and split doses of nitrogen fertilizer. The similar results were also found by Amanullah et al. [17]. The use of high rate of $\mathrm{N}$ increases heat units (thermal time) up to physiological maturity in maize crop [14]. These results are also corroborated with [15] who observed delayed maturity with increase in nitrogen rate because nitrogen delays vegetative growth and as a result delay maturity. Nitrogen application timing showed significant effect on days to physiological maturity of maize. Nitrogen and its application timings had significant effect on yield components (grains ear ${ }^{-1}$ and thousand grains weight) biological yield, grain yield and harvest index of maize. Number of grains ear $^{-1}$ increased with increase in nitrogen from 80 to $160 \mathrm{~kg} \mathrm{ha}^{-1}$. The lower total of grains ear-1 was noticed in the control plots. The probable reason of less number of grains ear ${ }^{-1}$ in control plots might be nitrogen absence and also less dry matter buildup. The remarks of [18] supported our results about the increase in number of grains ear ${ }^{-1}$ with increase in nitrogen. [19] also quoted that grains ear $^{-1}$ increased with increase in $\mathrm{N}$ rates. The more number of grains ear ${ }^{-1}$ could be the reason of less nutrient competition at high $\mathrm{N}$ rates which 
will lead to more biomass production and as a result more photosynthates travel from source to sink. These outcomes are also in accordance to [6] that by applying high rate of nitrogen produced more number of grains ear $^{-1}$. Control gave less grains ear $^{-1}$ as compared to plots treated with nitrogen [14]. In case of AT more grains ear ${ }^{-1}$ were counted in plots supplied with $\mathrm{N}$ half at sowing plus half at 25 days after sowing while less grains ear ${ }^{-1}$ were recorded in plots to which nitrogen was applied full at sowing time. These results are in accordance with the findings of [16] who stated that $\mathrm{N}$ application in three splits can give maximum number of grains $\mathrm{cob}^{-1}$. Similarly [20] also found a significant difference in number of grains ear ${ }^{-1}$.

Increase in $\mathrm{N}$ rates leads to increase in thousand grains weight of maize. Lower thousand grains weight was noticed in control plots while those plots which were treated with $160 \mathrm{~kg} \mathrm{~N}$ ha $^{-1}$ gave highest thousand grains weight. This might be due to balance nutrient availability in fertilized plots which boosted the photo assimilates and increased the grain weight. Our findings are in accordance with [21]. Applying nitrogen in 2 splits showed optimum thousand grains weight. Possibly it may be the result of less nitrogen percolating and more availability to the maize plant and also the nitrogen use efficiency is improved. More dry matter produced by those plants taking more nitrogen in the process of photosynthesis. Results are in link with that of [22]. These results are further supported by Radma and Dagash [23].

A linear increase was observed in biological yield of maize by increasing $\mathrm{N}$ and higher biological yield was recorded in plots received $160 \mathrm{~kg} \mathrm{~N} \mathrm{ha}^{-1}$. The findings are in conformity with [24] who observed a significant increase in vegetative biomass by the application of higher $\mathrm{N}$ rates that is directly proportional to enhanced biological yield. Regarding AT maximum biological yield was noticed in plots supplied with nitrogen, $50 \%$ at sowing plus $50 \%$ at 25 days after sowing. Our results are supported by Nemati and Sharif [20] who found a significant difference in biological yield of maize.

Nitrogen at the rate of $160 \mathrm{~kg} \mathrm{ha}^{-1}$ and its application at AT2 gave maximum grain yield. Control plots gave lower grain yield as compare to fertilized plots. These findings are parallel to that of [25], they observed increase in grain yield by increasing $\mathrm{N}$ levels. In case of application timings, nitrogen half at sowing plus half at 25 days interval of sowing gave maximum grain yield. The full dose of nitrogen fertilizers at once is therefore not suggested because it leads to losses as the plant cannot utilize all the fertilizer at once, so to enhance $\mathrm{N}$ use efficiency and yield it is advised to use it in splits rather than sole application at the time of planting [26]. Our results are further supported by Tadesse et al. [27] who observed that nitrogen application of $1 / 4$ at planting $+3 / 4$ at knee height considerably increased yield and yield components of maize.

Harvest index was seen to be significantly altered by $\mathrm{N}$ levels. The increase synthesis of dry matter as a result of photosynthesis and the significant interference of active enzymes due to the use of $\mathrm{N}$ in inert form led to more harvest index in corn [28]. [29] stated that whenever, yield and yield components increases, a positive association might be there for harvest index of corn. [30] also described that optimum harvest index was acquired when $\mathrm{N}$ was applied in high doses to corn crop.

\section{Conclusion}

Nitrogen is very much important for increasing yield. Right dose and at right application time of $\mathrm{N}$ improved nitrogen use efficiency of maize. Split application of $\mathrm{N}$ is suitable to attain optimum maize yield. 
Timing of $\mathrm{N}$ application is also deliberated as the best managing strategy and is very crucial for maize production. It was concluded from the research that yield and yield components of maize perform better when fertilized with nitrogen at the rate of $160 \mathrm{~kg} \mathrm{ha}^{-1}$. In addition to that $1 / 2 \mathrm{~N}$ applications at sowing $+1 / 2$ at 25 days after sowing of $\mathrm{N}$ fertilizer gave better results.

\section{Authors' contributions}

Conceived and designed the experiments: $\mathrm{S}$ Anwar \& W Ullah, Performed the experiments: W Ullah, Data collection and field inspections: W Ullah, S Anwar, M Islam \& M Shafi, Statistical analysis of the data: M Shafi, M Islam \& A Iqbal, Contributed reagents/ materials/ analysis tools: S Anwar, M Shafi \& M Alamzeb, Wrote the paper: S Anwar \& W Ullah.

\section{References}

1. Harris D, Rashid A, Miraj G, Arif M \& Shah H (2007). 'On-farm' seed priming with zinc sulphate solution-a costeffective way to increase the maize yields of resource-poor farmers. Field Crops Res 102: 119-121.

2. MINFAL (2012). Agricultural statistics of Pakistan. Govt. of Pakistan. Ministry of Food Agri. Livestock, Food Agricultural and Livestock, Division (Economic wing) Islamabad.

3. Ahmad N (2000). Fertilizer Scenario in Pakistan Policies and Development. In: Proceedings of the conference: Agriculture and Fertilizer Use. Planning and Development Division, Government of Pakistan, February 15-16, NFDC, Islamabad, Pakistan.

4. Shah Z, Shah SH, Peoples MB, Schwenke GD \& Herriedge DF (2003). Crop residue and fertilizer $\mathrm{N}$ effects on nitrogen fixation and yields of legumecereal rotations and soil organic fertility. Field Crops Res 83: 1-11.

5. Azeez JO \& Adetunji MT (2007). Nitrogen use efficiency of maize genotypes under weed pressure in a tropical alfisol in Northern Nigeria. Tropicultura 25(3): 174-179.

6. Rizwan M, Maqsood M, Rafiq M, Saeed M \& Ali Z (2003). Maize (Zea mays L.) response to Split application of Nitrogen. Intl J Agric Biol 1560-8530.

7. Ferguson RB, Hergert GW, Schepers JS, Gotway CA, Cahoon JE \& Peterson TA (2002). Site specific nitrogen management of irrigated maize: Yield and soil residual nitrate effects. Soil Sci Soc American J 66: 544-553.

8. Al-Kaisi MM \& Yin X (2003). Effect of nitrogen rate, irrigation rate, and plant population on corn yield and water use efficiency. Agron J 95: 1475-1482.

9. Gehl RJ, Schmidt JP, Maddux LD \& Gordon WB (2005). Corn yield response to nitrogen rate and timing in sandy irrigated soils. Agron J 97: 1230-1238.

10. Walsh OS (2006). Effect of Delayed Nitrogen Fertilization on Corn Grain Yields. M. Sc. Thesis. Graduate College. Oklahoma State Uni., Oklahoma.

11. Steel RGD \& Torrie JH (1996). Principles and Procedures of Statistics. 2nd Ed. McGraw Hill Book Co. Inc Singapore 172-178.

12. Amanullah, Khattak RA \& Khalil SK (2009). Effects of plant density and $\mathrm{N}$ on phenology and yield of maize. J Plant Nutr 32: 246-260.

13. Ali K, Munsif F, Zubair M, Akbar $\mathrm{H}$ Hussain Z, Shahid M, Din I \& Khan N (2011). Management of organic and inorganic nitrogen for different maize varieties. Sarhad J Agric 27(4): 525-529.

14. Imran S, Arif M, Khan A, Khan MA, Shah W \& Latif A (2015). Effect of nitrogen levels and plant population on yield and yield components of maize. Adv Crop Sci Tech 3(2): 2-7.

15. Wajid A, Ghaffar A, Maqsood M, Hussain K \& Nasim W (2007). Yield response of maize hybrids to varying 
nitrogen rates. Pak J Agri Sci 44(2): 217220.

16. Hammad HM, Ahmad A, Wajid A \& Akhter J (2011). Maize response to time and rate of nitrogen application. Pak $J$ Bot 43(4): 1935-1942.

17. Amanullah, Bashir SF, Qahar A, Shah S, Ahmad B \& Iqbal A (2015). Interactive effects of nitrogen and sulfur on growth, dry matter partitioning and yield of maize. Pure Appl Biol 4(2): 164-170.

18. Sanjeev K \& Bangarwa AS (1997). Yield and yield components of witer maize (Zea mays L.) as influenced by plant density and nitrogen levels. Agricultural Science Digest (Karnal) 17: 181-184.

19. Torbert HA, Potter KN \& Morrison JE (2001). Tillage system, fertilizer nitrogen rate and timing effect on corn yields in the Texas Blackland prairie. Agron J 93: 1119-1124.

20. Nemati AR \& Sharif RS (2012). Effects of rates and nitrogen application timing on yield, agronomic characterstics and nitrogen use efficiency in corn. Int $J$ Agri Crop Sci 4(9): 534-539.

21. 21. Alam N, Hayat K, Zubair M, Zaman Q \& Aziz A (2003). Adaptability of maize application methods to D.I. Khan's ecology. Indus J Plant Sci 4(2): 191-195.

22. Liu K \& Wiatrak P (2011). Corn production and plant characteristics response to $\mathrm{N}$ fertilization management in dry-land conventional tillage system. Int J Plant Prod 5: 405-416.

23. Radma IAM \& Dagash YMI (2013). Effect of different nitrogen and weeding levels on yield of five maize cultivars under irrigation. Univ J Agric Res 1: 119-125.

24. Zubhair M, bakhat J \& Shafi M (2009). Effect of method and nitrogen levels of nitrogen application on wheat varieties. M.Sc (Hons). Thesis, Dept Agron Agri Univ Peshawar, Pakistan.

25. Akmal M, Rehman H, Farhatullah, Asim M \& Akbar H (2010). Response of maize varieties to nitrogen application for leaf area profile, crop growth, yield and yield components. Pak J Bot 42(3): 1941-1947.

26. Sainz HR, Echeverria HE \& Barbieri PA (2004). Nitrogen balance as affected by application time and nitrogen fertilizer rate in irrigated no-tillage maize. Agron J 96: 1622-1631.

27. Tadesse $T$, Assefa A, Liben $M$ \& Tadesse Z (2013). The effect of nitrogen fertilizer split application on the nitrogen use efficiency, grain yield and economic benefit of maize production. Int J Agric Sci 3(5): 493-499.

28. Khaliq T, Mahmood $\mathrm{T} \&$ Masood A (2004). Effectiveness of farmyard manure, poultry manure and nitrogen for corn (Zea mays) productivity. Intl $J$ Agric Bio 2: 260-263.

29. Rasheed M, Ali H \& Mahmood T (2004). Impact of nitrogen and sulfur application on growth and yield of maize (Zea mays L.). Crop J Res Sci 15: 153157.

30. Zeidan MS, Amany A \& El-Kramany B (2006). Effect of N-fertilizer and plant density on yield and quality of maize in sandy soil. Res J Agric Biol Sci 2(4): 156-161. 